\title{
Using Mind Maps to motivate the digital generation of students to learn foreign languages
}

\author{
Irina Odaryuk ${ }^{1, *}$ \\ ${ }^{1}$ Rostov State Transport University, 2, Rostovskogo Strelkovogo Polka Narodnogo Opolcheniya Sq., \\ Rostov-on-Don, 344038, Russia
}

\begin{abstract}
The purpose of this research is to study the possibilities of using mind-mapping technology in modern conditions of digital transformation of the educational process to develop students' motivation to learn foreign languages. The research methods are the method of static description of the material, analysis, comparison and generalization of scientific information, and experiment. As a result, it was proved that the use of this technology in teaching foreign languages facilitates memorization of lexical material, promotes the development of speech skills, and makes the learning process exciting. It was found that in the course of creation of Mind Maps, students with a high level of digital skills are more successful in overcoming the language barrier, striving to expand the semantic components of Mind Maps. The scientific novelty lies in the fact that for the first time the students' preferences on the choice of methods of learning foreign languages were studied. To pioneer the use of the method, the study was carried out on special German texts, which were studied by the students by means of two methods (traditional and mindmapping technology).
\end{abstract}

\section{Introduction}

The digital transformation of the Russian education system, which had to be launched in March 2020, led to a renewal of the educational process. The educator and learners are now in constant interaction, organized by means of the Internet. The combination of digital technologies and traditional teaching methods provides an opportunity to expand educational services, the geography of their provision, systematize methodical material, and positively influence the students. Among scientists, there is the opinion that in the process of continuing education in full-time format, certain elements of e-learning will be preserved and will be used in the future [1]. T.E. Isaeva declares the emergence of a new organizational and methodological form of education. The author defines complementary education as the modelling of the educational process by voluntary combination of full-time work of teachers and students with distance forms of education [2].

\footnotetext{
* Corresponding author: odar-irina@yandex.ru
} 
For the implementation of distance education in each university, the Electronic Information and Educational Environment (EIEE) was created and further developed. The positive aspects of its application in the educational process are noted by Russian and foreign researchers. The electronic environment facilitates successful communication between teachers and students, enhances student learning in communities, provides students with the opportunity to take e-learning courses, and fosters the integration of student elearning experiences with academic experience at universities. The authors also emphasize the possibility of developing interest and increasing student achievement through the use of EIEE [3, 4]. To enrich EIEE, university teachers have developed various methodical and didactic materials, teaching methods and technologies [5]. It should be noted that the process of technical development and updating of the educational content of the EIEE in accordance with the changes in the requirements of the Federal State Educational Standards is constantly carried out in each university [6].

However, the analysis of the experience of the remote learning during the pandemic revealed some shortcomings. Many authors point to the difficulty of objectively assessing of students' knowledge, since there was no direct face-to-face communication between students and the teacher. The poor percentage of students' personal computers and Internet access also negatively influence the process of education digitalization [7]. Psychologists note that independence, consciousness, self-discipline, and a desire to learn are essential qualities that contribute to the success of distance learning [8]. Students' lack of selfcontrol and self-organization skills, insufficient control by teachers led to a decrease in students' motivation to learn, including foreign languages. It is known that a student with a low level of motivation will not be able to form the professional competences necessary for his/her professional development [9].

The first stage of informatization has been implemented and it is necessary to move to the next stage of education digitalization. Digital transformation of education is understood as the achievement of the necessary educational results and movement towards the personalization of the educational process through the use of digital technologies (hereinafter referred to as DT) [10]. This is possible only through the use of updated didactic approaches, the development and use of innovative methodical tools [5]. The search for such teaching technologies, the peculiarities of their application in the context of the transformation of education determine the relevance of this study.

DT are used as a tool to develop innovative, highly effective teaching methods. They provide an opportunity to use such types and methods of organizing educational activities that the teacher previously could not apply in the educational process due to the complexity of their implementation by means of conventional (paper) methods [10]. Mind Maps technology occupies a special place among such technologies. There are different names for this technique (mental map, mind map, conceptual map), but all of them are based on the graphic technique of recording and structuring information that is included into concepts. The concept as a culturally determined unit of communication in a certain subject area [11] is depicted in the form of various figures in which short statements (a word, a phrase) are inscribed. The lines connecting the shapes show the relationships between concepts. Connecting words or phrases on the lines explain the type of ties between the concepts [12], The possibilities of mind maps have expanded with the development of DT. In this study, Mind Maps, created online, is considered as a digital teaching technology.

S.S. Yakovleva points to the relevance of the use of Mental maps in various spheres of human life, such as planning of events, discussing meeting issues, employees training, creative problems solving, etc. [13]. Many scientists have considered the possibility of using mind-mapping technology in the educational process in the study of various disciplines [14-18]. L.A. Sazanova believes that the use of Mental maps contributes, according to Russian Federal State Educational Standard $3++$, to the preparation of Master 
Program students for solving problems of professional activity (organizational, managerial, pedagogical) [19]. E.A. Zlobina defines Mind maps as techniques for visualizing of thinking and considers their possibilities for activating the process of learning foreign languages [20]. Most authors explore the possibilities of Mind maps in traditional (paper) format. T.A. Tantsyura studies in sufficient detail the problems of motivating students to learn foreign languages when switching to remote learning. The use of methods and educational means that affect the change in the students' interests and needs can become the motive for foreign language learning, according to the author [21].

However, the new generation of students differs significantly from the previous generations, their parents and teachers with many years of experience. Students born in the information society are more dependent on digital technologies than their parents. They are used to being in constant Internet interaction. Representatives of this generation are impatient and focused on short-term goals, less ambitious than children of previous generations. They grew up in a digital environment and are used to getting all information quickly and effortlessly from the Internet. They mostly read mini-news, tweets, social media statuses. Fragmentation and superficiality are thinking characteristic of the representatives of the digital generation. But these features of their mental development allow them to solve several problems simultaneously, instantly single out the necessary information [8]. It is these features that should be taken into account when choosing teaching methods for modern students. The forms and methods of teaching used by teachers of the older generation often lead to a decrease in interest in teaching.

As an alternative, we offer Mind Maps (mind-mapping) technology, updated and adapted to modern learning conditions. The changed students' attitude towards learning, the enthusiasm for mobile applications, fragmented perception, the ability to grasp quickly important information should be used to create sustainable motivation for learning. Using the positive experience of students in self-education, relying on their knowledge will lead to the moment when the student will show interest and feel able to complete the proposed task. To do this, one should entrust the creation of Mind maps to the students themselves. The teacher, in accordance with the main provisions of the practice-oriented methodology, is a consultant, coordinator for working on texts and creating Mind Maps [22].

The analysis of the experience to use mental maps in the educational process of universities shows that they are successfully used at various stages of the lesson:

- during the introduction of new training material [14];

- during the control of the acquired knowledge [15];

- in the joint activity of teachers and students in an interactive form at the main stage of the lesson [13; 19];

- at the stage of reflection at the end of the lesson [13].

We offer the use of Mind Maps technology at other stages of a foreign language lesson, for example, when studying vocabulary and developing speaking skills in accordance with the topics of the discipline's work program. To do this, students work in the mobile application https://www.mindmaps.com in real time, combining the power of mind maps with the advantage of online collaboration. They familiarize themselves with the text of the textbook, choose keywords, main ideas and put it in the form of a mind map. Students have the opportunity to send to the teacher or to their friends the maps they have created, discuss the options for the components of the map, correct, replace them, while involuntarily memorizing the vocabulary on the topic and forming the basis for future statements.

The purpose of this study is to test the Mind Maps as a modern educational technology that helps to instill the interest of modern students in the study of foreign languages. To achieve this goal, it is planned to solve the following tasks: 
- to study the features of the education development in the transition period;

- to study the individual psychological conditions for the personality formation of a new generation of students;

- to analyze the possibilities of using Mind Maps technology as a means of motivation for learning foreign languages;

- to conduct an experiment in order to identify students' preferences in the choice of teaching methods for a foreign (German) language.

The research question is as follows:

- How effective is Mind Maps technology in motivating modern students to learn foreign languages?

The research includes an introduction, description of the experimental technique, description of the research results, discussion and conclusion.

\section{Materials and methods}

To answer the research question stated in the Introduction - how well does Mind Maps technology work to generate the digital generation students' interest in learning foreign languages, - we conducted a pilot study. The subject of the research was students' preferences in choosing a method (innovative or conventional) of learning to consolidate lexical potential and develop speech skills in a foreign language. The experimental methodology includes a survey method, a method for quantifying data, studying and comparative analysis of the information received, as well as a method for summarizing the results.

The participants of the experiment were a combined group of freshmen (20 people) of the Rostov State Transport University. Henceforth we will refer to them as "experts". In accordance with the curriculum, the students study the subject "Foreign Language" (German), use the Mind Maps technology and the conventional method (question-andanswer exercises) when working with texts. This indicates that the experts know the essence of problem and have some experience in the application of these technologies in educational activities.

The purpose of the experiment is to study the possibility of using the Mind Maps technology to develop motivation of modern students to learn foreign languages. In accordance with the research question and design, we formulated a research hypothesis: the use of innovative teaching methods in educational activities contributes to the effective formation of skills and abilities that make up a foreign language information competence, which increase the motivation of modern students in improving their knowledge of a foreign language. The questionnaire was compiled on the basis of the updated didactic principles of teaching foreign languages [2]. The survey was conducted in February, 2021. The experts were given the opportunity to examine the presented criteria that determine the possibilities of using both methods in the study of vocabulary and development of speech skills in a foreign language. The assessment was conducted according to a five-point system. The experts were able to compare the advantages of both methods for the proposed items and filled in the questionnaires quickly and without any hesitation.

\section{Results}

The result of the quantitative calculation of evaluations that contained a positive attitude (4 and 5) are presented in the table (see Table 1). The participants of survey did not give neutral (3) or negative ratings (1-2). 
Table 1. Results of the students' survey on the assessment of educational technologies used in teaching foreign languages.

\begin{tabular}{|l|l|c|c|c|c|c|c|}
\hline No & \multicolumn{1}{|c|}{$\begin{array}{c}\text { Assessment } \\
\text { criteria }\end{array}$} & \multicolumn{2}{c|}{$\begin{array}{c}\text { Mind Maps } \\
\text { Technology }\end{array}$} & \multicolumn{2}{c|}{$\begin{array}{c}\text { Conventional } \\
\text { method }\end{array}$} & \multicolumn{2}{c|}{$\begin{array}{c}\text { Method preference } \\
(+)\end{array}$} \\
\hline & \multicolumn{1}{|c|}{$\begin{array}{c}\text { Response } \\
\text { rate }\end{array}$} & $\begin{array}{c}\text { Response } \\
\text { rate }\end{array}$ & $\begin{array}{c}\text { Mind } \\
\text { Maps } \\
\text { Technology }\end{array}$ & $\begin{array}{c}\text { Conven } \\
\text { tional } \\
\text { method }\end{array}$ \\
\hline 1 & Visibility of & 18 & 90 & 2 & 10 & +80 & \\
\hline 2 & $\begin{array}{l}\text { Clarity } \\
\text { assignment }\end{array}$ & 20 & 10 & 0 & 0 & +100 & \\
\hline 3 & Cognitive activity & 15 & 75 & 5 & 25 & +50 & \\
\hline 4 & $\begin{array}{l}\text { Self-control and } \\
\text { self-correction }\end{array}$ & 12 & 60 & 8 & 40 & +20 & \\
\hline 5 & Critical thinking & 14 & 70 & 6 & 30 & +40 & \\
\hline 6 & Creativity & 16 & 80 & 4 & 20 & +60 & \\
\hline 7 & $\begin{array}{l}\text { Emotional } \\
\text { perception }\end{array}$ & 17 & 85 & 3 & 15 & +70 & \\
\hline 8 & Motivation & 19 & 95 & 1 & 5 & +90 & \\
\hline 9 & $\begin{array}{l}\text { Removing } \\
\text { language barriers }\end{array}$ & 12 & 60 & 8 & 40 & +20 & \\
\hline 10 & Novelty & 13 & 65 & 7 & 35 & +30 & \\
\hline 11 & Efficiency & 16 & 80 & 4 & 20 & +60 & \\
\hline & & & & & & \\
\hline
\end{tabular}

The interpretation of the data obtained allows us to conclude that the innovative method of teaching foreign languages prevails over the conventional one. The Mind Maps technology received an overwhelming number of positive ratings for all the suggested positions. The criterion "Visibility" received $100 \%$ positive ratings, which is quite fair, since the visual representation of the necessary information is one of the main characteristics of this method. Most experts highly rated the following positions: "Clarity of the task" (+ 80\% compared to the traditional method), "Emotional perception" $(+70 \%)$, "Cognitive activity" (+75\%), "Critical thinking" $(+40 \%)$, "Creativity" $(+60 \%)$. This result is associated with the psychological characteristics of experts who are representatives of the digital generation. They prefer to receive tasks:

- in a clearly and precisely formulated form;

- that are affecting the emotional sphere;

- developing cognitive activity, analysis, search for solutions, promoting memorization;

- developing critical thinking and creativity.

"Self-control and self-correction" prevail only by $20 \%$, which is possibly due to the fact that the experts are freshmen and have not yet weaned from total teacher control. On the item "Removing of language barriers", the scores were $60 \%$ and $40 \%$, respectively. For $65 \%$ of experts, this method turned out to be new in learning foreign languages. $35 \%$ of students are already familiar with Mind Maps technology and have used it in other subjects. According to the majority of experts (95\%), it is easier and more interesting to complete the task with the help of the new method and due to the possession of digital devices. The prevalence of the innovative method in terms of "Efficiency" is $60 \%$. Consequently, the hypothesis presented by us was confirmed. 


\section{Discussion}

The experiment has shown that the overwhelming majority of students $(95 \%)$ believe that using Mind Maps technology contributes to the formation of motivation for learning foreign languages. The results of the study coincide with the opinions of many scientists who argue that it is information and communication technologies that are effective when teaching the modern digital generation of students [8, 13, 16, 23-26].

Working with Mental maps in educational activities contributes to the development of students' creative thinking, memorization of information and organization of mental activity, the ability to synthesize acquired knowledge, highlight a problem and see ways to solve it, as well as analyse the results [12, 27-29].

The conclusion of our study confirms the data obtained earlier by E.A. Zlobina when conducting an experiment to identify the possibilities of using mental maps in foreign language classes for postgraduates. $85 \%$ of the participants in the experiment noted that they more easily complete the task of drawing up a text plan using a Mind map than with the case of conventional tasks. They explain this by the fact that the Mind map is created on the basis of associative logic. Key words appear sequentially, one can work out the details for each branch of the Mind map, and as a result of this work, a holistic picture is formed [20] G.V. Kravchenko and E.A. Petukhova conducted a comparative experiment on the effectiveness of mental maps in teaching the course "History and Methodology of Mathematics and Informatics", using a paper version of the map design. The participants in the experimental group showed high results in learning [30].

Modern students assimilate emotionally meaningful information better, because their thought process is based on images and emotions. Scientists also note that the acceleration of the life pace, the fragmentation of information lead to the unification and simplification of thinking, often its transition into the sphere of the unconscious [8]. This requires a visual presentation of educational material, the use of digital technologies in teaching, which is also proven by the results of our experiment (see Table 1, items 1, 7).

There is an opinion that the collaborative aspects of mind mapping are poorly understood in comparison with other possibilities of mental maps. Research on the creation of Mind maps in pairs, small and large groups is of interest to scientists, because the results of these observations could be applied to the development of mental maps' theory [31].

As practice shows, mental maps work effectively only if learners create their own schemes. The peculiarities of their perception are directly related to active mental activity. Students do not analyse the mental maps prepared by the teacher and do not remember well, for example, a drawing made after a training material and suggested as a visual conclusion or a mental map without explanations. To activate the thinking process, students are offered tasks that contribute to an independent search for solutions, for example: 1) fill in the next unit of the mental map; 2) complete the missing unit; 3) remove the false unit and replace it with the correct one. The main advantage of this technique is that students do not memorize an oral topic, but reproduce it in the course of presenting a metal card they have created.

The search for new opportunities of this technology continues. Modern online programs help to quickly and beautifully build mental maps, attach additional information (video, audio), add links to Internet resources, save in digital format, download, send to group members. Mind maps built using online services represent the backbone of the interactive digital technology Mind Maps.

It should be noted nevertheless some difficulties in the application of this technology. Lack of regular access to the Internet, teachers' lack of skills to use these programs, low level of students' foreign language proficiency and some other can reduce the effectiveness of the use of Mind Maps technology in educational activities [32, 33]. 


\section{Conclusion}

The challenges of the modern society have caused the digital transformation of education and the formation of a new generation of students. Accordingly, new learning technologies are required. To make the learning process more efficient and rational, information and communication technologies are needed because they correspond to the thinking style of modern students and help to increase students' motivation for the subject being studied.

The search and development of such methods and technologies is one of the main tasks of a modern teacher and is directly related to his/her didactic competence. Mind Maps or mind-mapping interactive technology is considered as a promising technology in education. Its application on the basis of modern online services contributes to the formation of critical thinking and creativity of modern students. The potential of Mind maps allows to transform learning into a personal, exciting, and highly motivating activity.

This technology is also relevant in teaching foreign languages. The organization of the educational process with the help of mental maps contributes to the development of speech skills and abilities, improves the quality of knowledge and leads to instilling students' interest in foreign languages. The experimental data indicate that students highly appreciated the capabilities of mind-mapping technology. The practical significance of the research lies in the fact that its results can be applied in the process of learning foreign languages and other disciplines at different levels of education.

A continuous search for the most successful, innovative didactic solutions, the discovery of new learning opportunities, an expert assessment of pedagogical technologies make a strategy for further research within the framework of the stated problem.

\section{References}

1. S. Kusina, I. Sagiryan, E. Krasnova, V. Barashyan, Modern Global Economic System: Evolutional Development vs. Revolutionary Leap, in Proceedings of ISC 2019, 198, (2019), doi.org/10.1007/978-3-030-69415-9_76

2. T. E. Isaeva, Modern digital and information-and-communicational technologies of forming universal competences of university students in the process of foreign languages teaching [Sovremennye tsifrovye i informatsionno-kommunikatsionnye tekhnologii formirovaniya universal'nykh komtetentsiy obuchayusshikhsya universitete $\mathrm{v}$ protsesse obucheniya inostrannym yazykam], 248 (2020), [In Russ.]

3. A. Bozkurt, Handbook of Research on Learning in the Age of Transhumanism, 252273 (2019), doi.10.4018/978-1-5225-8431-5.ch016

4. H. J. Kim, A. J. Hong, H.-D. Song, International Journal of Educational Technology in Higher Education, 16 (2019), doi.org/10.1186/s41239-019-0152-3

5. N. B. Strekalova, Samarsk Scientific Bulletin. History. Pedagogy. Philology. [Samarskiy Nauchniy Vestnik. Istoriya. Pedagogika. Filologiya], 25, 84-88 (2019), [In Russ.], http://doi.org/10.18287/2542-0445-2019-25-2-84-88

6. I. V. Odaryuk, I. Kotliarenko, Samarsk Scientific Bulletin [Samarskiy Nauchniy Vestnik], 2(31), 339-344 (2020), [In Russ.], doi.10.17816/snv202309

7. O. V. Shmurygina, Vocational Education and Labour Market [Professional'noye Obrazovanie i Rynok Truda], 2, 51-52 (2020), [In Russ.], doi.10.24411/2307-42642020-10210

8. O. Chekun, I. Lushnikova, Theory and Methods of Vocational Education [Teoriya i Metodika Professional'nogo Obrazovaniya], 1, 69-73 (2015), [In Russ.]

9. T. Isaeva, N. Malishevskaya, L. Cherkasova, A. Kolesnichenko, In Proceedings of ITSE-2020, 210, 01001-22041 (2020), https://doi.org/10.1051/e3sconf/202021018071

10. A. Uvarov, E. Gable, I. Dvoretskaya, et al., Difficulties and prospects of digital 
transformation of education [Trudnosti I perspektivy tsifrovoy transformatsii obrazovaniya], 343 (2019), [In Russ.], doi.10.17323/978-5-7598-1990-5

11. O. Marunevich, I. Odaryuk, Juridical science in the 21-st century: relevant problems and prospects of their solution [Yuridicheskaya nauka v 21 veke: aktual'nye problem i perspektivy ikh resheniya], 171-173 (2020), [In Russ.]

12. T. Byuzen, Intellectual cards [Intellekt-karty], 208 (2019), [In Russ.]

13. S. S. Yakovleva, Scientific Review, 4, 134-139 (2019), [In Russ.]

14. A. Babich, Effective information processing (Mindmapping). [Effektivnaya obrabotka informatsii], 281 (2016), [In Russ.]

15. E. Dronova, Problems of the Modern Education [Problemy Sovremennogo Obrazovaniya], 2, 118-124 (2017), [In Russ.]

16. K. Tee, J. M. Yunjos, B. B. Mohammad, W. Othman, Procedia - Social and Behavioral Sciences, 69, 705-708 (2012), doi.10.1016/j.sbspro.2012.11.464

17. I. M. A. Jbeili, Procedia - Social and Behavioral Sciences, 103, 1078-1087 (2013), doi.org/10.1016/j.sbspro.2013.10.435

18. R. Wette, Journal of Second Language Writing, 38, 58-71 (2017), dx.doi.org/10.1016/j.jslw.2017.09.005

19. L. Sazanova, Prospects of Information Technologies Development [Perspektivy Razvitiya Informatsionnikh Tekhnologiy], 28, 118-122 (2016), [In Russ.]

20. E. A. Zlobina, Local and Foreign Pedagogy [Otechestvennaya I Zarubezhnaya Pedagogika], 3(68), 133-149 (2020), [In Russ.]

21. T. Tantsyura, World of Science, Culture, Education [Mir Mauki, Kul'tury, Obrazovaniya], 3(82), 281-283 (2020), [In Russ.], doi.10.24411/1991-5497-202000543

22. I. V. Odaryuk, The Teacher of a Higher School in the 21-st Century [Prepodavatel' Vysshey Shkoly v 21 Veke], 1, 257-261 (2016), [In Russ.]

23. S. A. Smirnova, Bulletin of Kuban State University [Vestnik KGU], 1, 143-146 (2017), [In Russ.]

24. N. Hidayati, S. Zubaidah, E. Suarsini, H. Praherdhiono, Universal Journal of Educational Research, 7(9A), 171-179 (2019), doi.10.13189/ujer.2019.071620

25. I. Simonova, Procedia - Social and Behavioral Sciences, 171, 1229-1234 (2015), doi.org/10.1016/j.sbspro.2015.01.236

26. M. Sun, M. Wang, R. Wegerif, British Journal of Educational Technology, 50(5), 2217-2233 (2019), doi.10.1111/bjet.12825

27. T. P. Gordienko, O. Yu. Smirnova, Problems of the Modern Pedagogic Education [Problemy Sovremennogo Pedagogicheskogo Obrazovaniya], 60(1), 89-92 (2018), [In Russ.]

28. M. Y. C. A. Kek, H. Huijser, Higher Education Research and Development, 30(3), 329-341 (2011), https://doi.org/10.1080/07294360.2010.501074

29. A. Kožuh, International Journal of Cognitive Research in Science, Engineering and Education (IJCRSEE), 8(1), 69-79 (2020), doi.10.5937/IJCRSEE2001069K

30. G. V. Kravchenko, E. A. Petukhova, Scientific Notes [Uchyonye Zapiski], Electronic Journal of Kursk State University, 3(47), 15 (2018), [In Russ.]

31. T.-J. Chen, R. Mohanty, V. K. Krishnamur, In Proceedings of ASME 2019 International Design Engineering Technical Conferences \& Computers and Information in Engineering Conference (IDETC/CIE 2019), 1-13 (2019)

32. M. Carrier, A. Nye, Digital Language Learning and Teaching, 208-221 (2017), doi.10.4324/9781315523293-18

33. R. Godwin-Jones, Using mobile devices in the language classroom: Part of the Cambridge Papers in ELT series, 24 (2018) 